\title{
Standard Criteria Response Mechanism of Pakistan Disaster Management Authority (PDMA) and Asian Development Bank (ADB): Evidence from Pakistan
}

\author{
Shariq Riaz Khattak \\ CECOS University of IT and Emerging Sciences \\ Peshawar, Pakistan \\ Zeeshan Ahad \\ IQRA National University \\ Peshawar, Pakistan \\ Dr. Muhammad Wasim Jan Khan \\ CECOS University of IT and Emerging Sciences \\ Peshawar, Pakistan \\ Sana Aroos Khattak \\ Lecturer: Capital University of Science and Technology \\ Islamabad, Pakistan
}

\begin{abstract}
Since the dawn of history and civilization human beings have suffered colossal losses due to natural and anthropogenic causes of various types, scales and dimensions. Floods and earthquakes of relatively recent past exposed the degree and vulnerability of Pakistan in general and Khyber Pakhtunkhwa (KPK) in particular. This study aimed to evaluate the capacity, affectivity and weakness of Pakistan Disaster Management Authority (PDMA) and compare and contrast it with the standards of Asian Development Bank (ADB). Data obtained through comprehensive questionnaires were processed through SPSS to determine the most important and least important five factors affecting disaster management in this specified region. The data analysis results of this study revealed and concluded that Pakistan Disaster Management Authority has yet to reach to a level where it is seen as a successful and effective organization that has the ability and capacity to deal with the mega disaster caused by natural and anthropogenic agents/sources.
\end{abstract}

Key words: Pakistan Disaster Management Authority, Asian Development Bank, Khyber Pakhtunkhwa, SPSS, Pakistan.

\section{INTRODUCTION}

Pakistan is one of the ten countries in the world, which is severely affected by extreme weather during 1995-2014 (David et al., 2017) and reconfirmed for the period 1996-2005 (Kreft et al., 2017). Three floods in 2010, 2011 and 2014 affected more than 30 million people and resulted in more than 14 billion dollars damages and losses caused to biolgocal and terrestial anquatic system. The accesessible information suggest that Pakistan sufferd heavily at the hands of these disasters because of the dearth of economical disasters management (Human Rights Commission of Pakistan, 2014). 
The disaster affected areas are controlled by a scientific method of disaster management that aims at minimizing the harm and facilitate the reconstruction of individuals to their traditional state (Mustafa \& Wrathall, 2011). Pakistan is well aware of the catastrophes that have caused an important toll in terms of men and material. However, due to its inadequate preparation to manage disaster, Pakistan is incapable of efficiently coping with natural calamities. An organized effort was though made to develop a viable structure of disaster management evolving into National Disaster Management Authority (NDMA), with the aim to realize the desired standards. The mega floods of 2010 and earth quake of 2005 terribly exposed the country's unpreparedness, vulnerability of the infrastructure and frail management leading to unprecedented proportion of losses and damages (Coppola \& Coppola, 2007). The magnitudes of implications of these colossal hazards were socio-economically, physically and even technologically un-measurable. Therefore, it became necessary to develop an imperative disaster management system to deal with mega hazards in a timely and befitting manner.

Technically arguing, a catastrophic event that brings great harm, destruction and devastation to life and property is called a disaster. The harm caused by disasters varies but the magnitude depends on geographical location, variability, climate severity and especially on the nature of disasters (Wisner et al., 2003). Cyclones, tsunami, floods, droughts, earthquakes and volcanoes are examples of natural disasters, whilst wars etc. fall within the class of the artificial disasters. These calamities and catastrophes cause significant impact upon living beings and their surroundings, however, the disasters are often slaked and losses are often reduced with economical preparation and management.

Disaster management is the mechanism of coordinative utilization of accessible resources to deal emergencies effectively, thereby saving lives, avoiding injuries and lessen the impact of disasters (Sayed \& Gonzalez, 2014). This conjointly deals with strategic and structure management processes to shield very important assets from hazard risks in such emergencies (UNDP Pakistan, 2017).

Disaster management could be a systematic method, consisting of four main phases: response, recovery, relief and rehabilitation; but it remains incomplete without mitigation and preparedness, which are basically pre-disaster management phases crucially necessary in managing disaster (Khan, 2016).

Mitigation is the first part of disaster management. It is a sustained action that reduces each short-run and long-run risk to individuals and property from the hazards and their effects. It involves activities like scientific hazard analysis, vulnerability analysis, risk assessment, avoiding construction in high risk zone, launching awareness campaigns, coaching and capability building of responders and managers. Mitigation therefore could be a persistent effort to decrease the impact that disasters might incur (Mata-Lima et al., 2013).

The second part of disaster management preparedness is outlined by Global Development Centre as "a set of steps that enhance the flexibility of communities and government to retort to a disaster." The steps included in this phase are resource inventory, reposition, supply coming up with, evacuation coming with, communication coming up with, and desires assessment. The key to effective disaster management is readiness to produce a speedy emergency response. It entails everybody to be ready to respond to extreme things. 
Response, a subsequent part of disaster management; includes the action of responding to associate in nursing emergency. It aims at producing immediate emergency support to a community taking care of health, safety and morale till a permanent solution is put in place.

The steps concerned with 'response' are: scenario analysis, crisis maps, info communication, evacuation and shelters, dispatching of resources and early harm assessment. Besides, trained associate in nursing, equipped personnel area needed to change a rising crisis.

Finally, recovery is that method of returning to traditional state of affairs in a given environment. It could also be short-run moreover as long run and it begins once the disaster commences. Recovery is overlapped by reconstruction, rehabilitation spatial coming up with, infrastructure buildings, housing, livelihood, social security, transport, clean beverage, communication and agriculture (Carter, 2008).

Floods with such magnitude had never been witnessed in the history of Pakistan. Torrential monsoon rains in Khyber Pukhtunkhwa, Sindh, and Baluchistan. The serious rains altogether affected the Indus river basin. Nearly 1/5 Pakistan submerged in water, with nearly twenty million people, destruction of property, living and infrastructure, and with the death toll of almost 2000. Had there been no institute to handle this natural catastrophe, the harm caused by floods would have been immeasurable and devastating (Munang et al., 2013).

However, despite the institution of National Disaster Management Authority (NDMA) the response was too slow to fulfil the magnitude of challenge. The aim behind its institution was to vary national response to emergency problems reactionary model to a full life mitigation, state, response and recovery model. NDMA is a government arm of the National Disaster Management Commission (NDMC) headed by Prime Minister. Also, NDMA supervises the Provincial Disaster Management Authorities (PDMA) and District Disaster Management Authorities (DDMA) (Mayhorn \& McLaughlin, 2014).

The National Disaster Management Authority has been given the task of coordinating the disaster risk management at the national level, implementing disaster risk management ways, mapping the hazards, developing pointers, making certain the institution of disaster management authorities and emergencies operation centre (EOC) at provincial, district and municipal levels. It provides technical help to the involved departments, organizing coaching to personnel, serving as lead agency for non-governmental organizations (NGOs) and international cooperation, coordinating with the centralized through National Emergency Operation Centre (NEOC) and requiring the department or agency to create there required resources and personnel (Marrone et al., 2013).

Disaster management in Pakistan significantly has for the most part remained unacceptable. The underlying factors accountable for its inefficiency, besides too little resources are lack of proactive approach and transparency. Moreover, this agency has nevertheless to prove its credibility, strategy and potency of infrastructure that lies at the heart of those vital things. Another issue that hampers the effective functioning of disaster management method is duplication of effort that arise attributable to the dearth of integration between varied agencies and the organizations concerned within the method. Consequently, these multiple factors render management method weak and therefore people have to bear its pressure.

Disaster proof housing mound of rivers, infrastructure, early warnings, fast evacuation, and nomination of danger zones before disaster, establishment of rescue centres creating public 
awareness concerning disasters, safety techniques would pave way towards a safer and secure future in terms of natural calamities. Disaster risk reduction would not produce immediate results because of which it requires sustained commitment on the part of the establishment, provincially and nationally. The governament must frame long-term strategies for the effective disaster risk management (Climate Change, 2014). This study is aimed to faciliate such strategies.

\section{RESEARCH OBJECTIVES}

This research aimed to determine more intricate understanding of PDMA performance in disaster response both prior to and after following the ADB disaster management criteria. This study seek to determine: (1) the public's reaction and response to PDMA in the aftermath of disaster, (2) Has the public opinion of PDMA changed after the handling of disaster?

\section{METHODOLOGY}

To obtain data for this study, a comprehensive questionnaire was developed in a well planned and best thought out manner to collect the required information. The final questionnaire was comprised of 25 questions with five points Likert Scale, covering all the important aspects of this study. A total of 66 questionnaires were personally distributed to the relevant individuals in various organizations and then collected; mainly PDMA staff in Khyber Pakhtunkhwa (KPK).

\section{DATA ANALYSIS}

The collected data was analysed through Statistic Package for Social Science (SPSS). Data for descriptive statistics including mean, standard error, median, mode, variances and standard deviation are given in table no. 2. The contribution of each of the factors to overall disaster response criteria were examined and the ranking of the attributes in terms of their criticality as perceived by the respondents was done by use of Relative Importance Index (RII) which was computed using the given equation and the results of the analysis are presented in table no. 1 to table no. 3 .

$$
\mathrm{RII}=\sum \mathrm{W} / \mathrm{A} * \mathrm{~N}(0 \leq \mathrm{RII} \leq 1)
$$

Whereas; $\mathrm{W}$ - is the weight given to each factor by the respondents and ranges from 1 to 5 , (as " 1 " is "very low", "2" is low, " 3 " is medium, " 4 " is high and " 5 " is "very high"); A - is the highest weight (i.e. 5 in this case) and; $\mathrm{N}$ - is the total number of respondents that is 66 .

\section{RESULTS AND DISCUSSIONS}

The overall analysis show the assessment of the awareness of disaster response criteria of ADB and PDMA, to identify the disaster response of PDMA, and to calculate the RII of respondents to determine the most important and least important factors affecting response criteria. Values of $\%$ frequency distributions based on the numerical weight-age given to classes as very low $=1$, low $=2$, medium $=3$, high $=4$ and very high $=5$ by the 66 respondents to all 25 questions are presented in table no. 1 and details of the descriptive statistics including mean $(\bar{x})$, standard deviations (SD), standard error of the mean, median, mode and variance are provided in table no. 2.

Table no. 3 shows RII for the individual questions as calculated by the equation in the proceeding section and ranked accordingly as per value of RII. Five most important factor affecting disaster response criteria are given in table no. 4, whereas the least important factors affecting disaster response criteria are given in table no. 5. Generally the ratings for all questions in the category of very high were comparatively low (0 to 18.2\%). The frequency 
distribution values of zero were observed, Q8 for PDMA seek help from international organization, Q12 for the level of understanding of the public of the risks of hazards in the country, Q15 for the level of training of PDMA official regarding disaster, Q23 for the level of volunteers response during crises and Q24 for the rating of your planning in case of disasters (Table no. 1). Minimum response or zero ranking was given only for the very high category while for Q8 and Q11, the ranking ranged between $9.1 \%$ (very low) to $48.5 \%$ (medium) and $15.2 \%$ (very low) to $33.6 \%$ (medium), respectively. For Q15, Q23 and Q25 the high category got $18.2 \%, 9.1 \%$ and $3.0 \%$ score, respectively (Table no. 1). The adequateness of media during disaster got the highest score of $18.2 \%$ as very high (Table no. 1). This reinforces the importance of the role of media in disaster awareness and management.

As per survey, $45.5 \%$ people considered that management team provides a correct survey of the affected people as medium while $48.5 \%$ thought PDMA seek help from international organization in the medium category, $30.3 \%$ in high and no one considered it as of very high category (Table no. 1). The response to the Q10, i.e. for rating whether other government departments facilitate the PDMA desiring crises was $42.4 \%$ as high (Table no. 1), which is quite positive and encouraging on part of the other departments.

The variability in the responses for various research questions can be seen from the values of $\bar{x} \pm \mathrm{SD}, \mathrm{SE}$ of the mean and the variance (Table no. 2). The $\bar{x} \pm \mathrm{SD}$ ranged from $2.21 \pm 0.85$ to $3.72 \pm 1.247$, SE of the mean varied from 0.11 to 0.153 , while, the variance ranged from 0.724 to 1.55 (Table no. 2). These values suggest reasonable variation in the responses of the target community and groups.

According to the RII values, the highly ranked question was, "PDMA future disaster planning and awareness" with RII value equal to 0.7455 and followed by adequateness of media during disaster with RII $=0.6909$ while the least RII was observed for level of understanding of the public of the risks of hazards in the country having rating of 0.4424 RII (Table no. 3). Based on the RII rankings, the five most and five least important factors are elaborated in the next section.

\section{FINDINGS AND RESULTS INTERPRETATIONS}

Based on the ranking, the values for the mean RIIs and the ranking of all groups are shown in Table 3, the top five most important factors affecting disaster response criteria and the five least important factors effecting disaster response criteria provided in table no. 4 and table no. 5 respectively. According to the ranking of the groups, the five factors of each that contribute most to affecting disaster response criteria are discussed below.

\section{PDMA future disasters planning and awareness (RII= 0.7454)}

PDMA future disasters planning and awareness is the most important factor according to the respondents affecting the disaster response criteria. It can be attributed to the ineffective planning for disaster. Poor planning and delaying in response to the disaster can lead to calamity. PDMA should follow the ADB criteria for planning and there planning should be revised if necessary.

This question asked at no. 25 , had the highest mean \pm SD of $3.72 \pm 1.24$ and $33.3 \%$ respondents considered it as very high and high (Table no. 1). It suggests that this is considered of critical importance by maximum people and must be addressed on priority basis. 
Table No. 1: Frequency Percentage (\%) of the Respondents Obtained for Response Mechanism of PDMA (n=66)

\begin{tabular}{|c|c|c|c|c|c|}
\hline Questions & $\begin{array}{l}\text { Very } \\
\text { Low }\end{array}$ & Low & Medium & High & $\begin{array}{l}\text { Very } \\
\text { High }\end{array}$ \\
\hline $\begin{array}{l}\text { 1. The level of warning system in preventing } \\
\text { the disasters }\end{array}$ & 18.2 & 36.4 & 21.2 & 18.2 & 6.1 \\
\hline $\begin{array}{l}\text { 2. Rank the awareness of community to the } \\
\text { warning system }\end{array}$ & 12.1 & 42.4 & 27.3 & 9.1 & 9.1 \\
\hline $\begin{array}{l}\text { 3. The response of people to the warning } \\
\text { system }\end{array}$ & 9.1 & 36.4 & 36.4 & 15.2 & 3.0 \\
\hline $\begin{array}{l}\text { 4. Rank the standard of readiness on part of } \\
\text { resource organization }\end{array}$ & 12.15 & 30.3 & 39.4 & 15.2 & 3.0 \\
\hline $\begin{array}{l}\text { 5. The level of public awareness program by } \\
\text { PDMA }\end{array}$ & 15.2 & 30.3 & 33.3 & 18.2 & 3.0 \\
\hline $\begin{array}{l}\text { 6. Response of PDMA in case of unexpected } \\
\text { magnitude of disaster }\end{array}$ & 12.1 & 21.2 & 33.3 & 24.2 & 9.1 \\
\hline $\begin{array}{l}\text { 7. Management team provides a correct survey } \\
\text { of the effected people }\end{array}$ & 18.2 & 15.2 & 45.5 & 18.2 & 3.0 \\
\hline $\begin{array}{l}\text { 8. PDMA seek help from international } \\
\text { organizations }\end{array}$ & 9.1 & 12.1 & 48.5 & 30.3 & 0.0 \\
\hline 9.The adequateness of media during disaster & 6.1 & 12.1 & 30.3 & 33.3 & 18.2 \\
\hline $\begin{array}{l}\text { 10. Rate other government departments } \\
\text { facilitate the PDMA during crises }\end{array}$ & 3.0 & 27.3 & 21.2 & 42.4 & 6.1 \\
\hline $\begin{array}{l}\text { 11. Level of preparedness of local communities } \\
\text { to mitigate natural disasters in your country }\end{array}$ & 15.2 & 33 & 33.6 & 15.2 & 3.0 \\
\hline $\begin{array}{l}\text { 12. The level of understanding of the public of } \\
\text { the risks of hazards in your country }\end{array}$ & 21.2 & 42.4 & 30.3 & 6 & 0.0 \\
\hline $\begin{array}{l}\text { 13. Level of inaccurate information effects the } \\
\text { planning }\end{array}$ & 9.1 & 21 & 27.6 & 27.3 & 15.3 \\
\hline $\begin{array}{l}\text { 14.That risk awareness and education } \\
\text { messages in your Country are consistent with } \\
\text { the "effective communication and education } \\
\text { tools" }\end{array}$ & 15.2 & 24.3 & 33 & 21 & 4.0 \\
\hline $\begin{array}{l}\text { 15. Level of the training of PDMA officials } \\
\text { regarding disasters }\end{array}$ & 18.2 & 30.3 & 33.3 & 18.2 & 0.0 \\
\hline $\begin{array}{l}\text { 16. The logistics problem in a disaster for } \\
\text { PDMA }\end{array}$ & 18.2 & 24.2 & 36.4 & 18.2 & 3.0 \\
\hline $\begin{array}{l}\text { 17. Level of broadcasting of warning } \\
\text { information to the public }\end{array}$ & 12.1 & 27.3 & 33.3 & 24.2 & 3.0 \\
\hline $\begin{array}{l}\text { 18. Level you see this statement is correct: } \\
\text { rescue, evacuation, shelter, food should be } \\
\text { provided by PDMA during crises }\end{array}$ & 6.1 & 18.2 & 27.3 & 33.3 & 15.2 \\
\hline $\begin{array}{l}\text { 19. Level of crisis communication and } \\
\text { cooperation of PDMA with community facilities } \\
\text { effective and timely }\end{array}$ & 9.1 & 24.2 & 45.5 & 15.2 & 6.0 \\
\hline
\end{tabular}




\begin{tabular}{|l|c|c|c|c|c|}
\hline $\begin{array}{l}\text { 20. Rate your response to the disaster at time of } \\
\text { crises }\end{array}$ & 12.1 & 21.2 & 27.3 & 30.3 & 9.1 \\
\hline $\begin{array}{l}\text { 21. Relation with metrological department for } \\
\text { the forecasting of disaster }\end{array}$ & 15.2 & 30.3 & 21.3 & 18.2 & 15.2 \\
\hline $\begin{array}{l}\text { 22. Rank the response of international } \\
\text { organization during crises }\end{array}$ & 3.0 & 27.3 & 21.2 & 36.4 & 12.1 \\
\hline $\begin{array}{l}\text { 23. The level of volunteer's response during } \\
\text { crises }\end{array}$ & 30.3 & 21.2 & 39.4 & 9.1 & 0.0 \\
\hline $\begin{array}{l}\text { 24. Rate your plans in case of different kinds of } \\
\text { disasters }\end{array}$ & 30.3 & 30.3 & 36.4 & 3.0 & 0.0 \\
\hline $\begin{array}{l}\text { 25. Rate your department about future } \\
\text { disasters planning and awareness. }\end{array}$ & 6.1 & 15.2 & 12.1 & 33.3 & 33.3 \\
\hline
\end{tabular}

Table No. 2: Descriptive Statistics of the Responses $(N=66)$ for 25 Questions of the Study Regarding PDMA Performance

\begin{tabular}{|l|l|c|c|c|c|}
\hline & Mean \pm SD & $\begin{array}{c}\text { Std. } \\
\text { Error } \\
\text { of } \\
\text { Quean }\end{array}$ & Median & Mode & Variance \\
\hline $\begin{array}{l}\text { Q1. The level of warning system in } \\
\text { preventing the disasters }\end{array}$ & $2.57 \pm 1.164$ & 0.143 & 2.00 & 2.00 & 1.356 \\
\hline $\begin{array}{l}\text { Q2. Rank the awareness of } \\
\text { community to the warning system }\end{array}$ & $2.60 \pm 1.107$ & 0.136 & 2.00 & 2.00 & 1.227 \\
\hline $\begin{array}{l}\text { Q3. The response of people to the } \\
\text { warning system }\end{array}$ & $2.66 \pm 0.950$ & 0.117 & 3.00 & $2.00^{\mathrm{a}}$ & 0.903 \\
\hline $\begin{array}{l}\text { Q4. Rank the standard of readiness } \\
\text { on part of resource organization }\end{array}$ & $2.66 \pm 0.982$ & 0.120 & 3.00 & 3.00 & 0.964 \\
\hline $\begin{array}{l}\text { Q5. The level of public awareness } \\
\text { program by PDMA }\end{array}$ & $2.63 \pm 1.047$ & 0.128 & 3.00 & 3.00 & 1.097 \\
\hline $\begin{array}{l}\text { Q6. Response of PDMA in case of } \\
\text { unexpected magnitude of disaster }\end{array}$ & $2.96 \pm 1.149$ & 0.141 & 3.00 & 3.00 & 1.322 \\
\hline $\begin{array}{l}\text { Q7. Management team provides a } \\
\text { correct survey of the effected people }\end{array}$ & $2.72 \pm 1.060$ & 0.130 & 3.00 & 3.00 & 1.124 \\
\hline $\begin{array}{l}\text { Q8. PDMA seek help from } \\
\text { international organizations }\end{array}$ & $3.00 \pm 0.894$ & 0.110 & 3.00 & 3.00 & 0.800 \\
\hline $\begin{array}{l}\text { Q9.The adequateness of media } \\
\text { during disaster }\end{array}$ & $3.45 \pm 1.112$ & 0.136 & 4.00 & 4.00 & 1.236 \\
\hline $\begin{array}{l}\text { Q10.Rate other government } \\
\text { departments facilitate the PDMA } \\
\text { during crises }\end{array}$ & $3.21 \pm 1.015$ & 0.125 & 3.00 & 4.00 & 1.031 \\
\hline $\begin{array}{l}\text { Q11. Level of preparedness of local } \\
\text { communities to mitigate natural } \\
\text { disasters in your country }\end{array}$ & $2.57 \pm 1.023$ & 0.126 & 3.00 & $2.00^{\mathrm{a}}$ & 1.048 \\
\hline $\begin{array}{l}\text { Q12. The level of understanding of } \\
\text { the public of the risks of hazards in } \\
\text { your country }\end{array}$ & $2.21 \pm 0.850$ & 0.104 & 2.00 & 2.00 & 0.724 \\
\hline
\end{tabular}




\begin{tabular}{|c|c|c|c|c|c|}
\hline $\begin{array}{l}\text { Q13.Level of inaccurate information } \\
\text { effects the planning }\end{array}$ & $3.18 \pm 1.201$ & 0.147 & 3.00 & $3.00^{a}$ & 1.443 \\
\hline $\begin{array}{l}\text { Q14.That risk awareness and } \\
\text { education messages in your Country } \\
\text { are consistent with the "effective } \\
\text { communication and education tools" }\end{array}$ & $3.27 \pm 3.330$ & 0.410 & 3.00 & 3.00 & 1.094 \\
\hline $\begin{array}{l}\text { Q15.Level of the training of PDMA } \\
\text { officials regarding disasters }\end{array}$ & $2.51 \pm 0.996$ & 0.123 & 3.00 & 3.00 & 0.992 \\
\hline $\begin{array}{l}\text { Q16. The logistics problem in a } \\
\text { disaster for PDMA }\end{array}$ & $2.63 \pm 1.076$ & 0.132 & 3.00 & 3.00 & 1.158 \\
\hline $\begin{array}{l}\text { Q17.Level of broadcasting of warning } \\
\text { information to the public }\end{array}$ & $2.78 \pm 1.045$ & 0.128 & 3.00 & 3.00 & 1.093 \\
\hline $\begin{array}{l}\text { Q18. Level you see this statement is } \\
\text { correct: rescue, evacuation, shelter, } \\
\text { food should be provided by PDMA } \\
\text { during crises }\end{array}$ & $3.33 \pm 1.127$ & 0.138 & 3.00 & 4.00 & 1.272 \\
\hline $\begin{array}{l}\text { Q19.Level of crisis communication } \\
\text { and cooperation of PDMA with } \\
\text { community facilities effective and } \\
\text { timely }\end{array}$ & $2.84 \pm 0.996$ & 0.122 & 3.00 & 3.00 & 0.992 \\
\hline $\begin{array}{l}\text { Q20. Rate your response to the } \\
\text { disaster at time of crises }\end{array}$ & $3.03 \pm 1.176$ & 0.144 & 3.00 & 4.00 & 1.384 \\
\hline $\begin{array}{l}\text { Q21.Relation with metrological } \\
\text { department for the forecasting of } \\
\text { disaster }\end{array}$ & $2.87 \pm 1.306$ & 0.160 & 3.00 & 2.00 & 1.708 \\
\hline $\begin{array}{l}\text { Q22.Rank the response of } \\
\text { international organization during } \\
\text { crises }\end{array}$ & $3.27 \pm 1.089$ & 0.134 & 3.00 & 4.00 & 1.186 \\
\hline $\begin{array}{l}\text { Q23.The level of volunteer's } \\
\text { response during crises }\end{array}$ & $3.27 \pm 1.000$ & 0.123 & 3.00 & 4.00 & 1.001 \\
\hline $\begin{array}{l}\text { Q24. Rate your plans in case of } \\
\text { different kinds of disasters }\end{array}$ & $3.12 \pm 0.886$ & 0.109 & 3.00 & 4.00 & 0.785 \\
\hline $\begin{array}{l}\text { Q25.Rate your department about } \\
\text { future disasters planning and } \\
\text { awareness. }\end{array}$ & $3.72 \pm 1.247$ & 0.153 & 4.00 & $4.00^{\mathrm{a}}$ & 1.555 \\
\hline
\end{tabular}


Table No. 3: Ranking of Relative Importance Index (RII) Affecting Disaster Response Criteria

\begin{tabular}{|l|l|c|c|}
\hline No & Important Factors Affecting Disaster Response Criteria & RII & Rank \\
\hline 1. & PDMA future disasters planning and awareness & 0.745455 & 1 \\
\hline 2. & The adequateness of media during disaster & 0.69090 & 2 \\
\hline 3. & $\begin{array}{l}\text { Rescue, evacuation, shelter food should be provided by PDMA } \\
\text { during crises }\end{array}$ & 0.666667 & 3 \\
\hline 4. & Level of volunteer's response during crises & 0.654545 & 4 \\
\hline 5. & Response of international organization during crises & 0.654545 & 5 \\
\hline 6. & Plans in case of different kinds of disasters & 0.624242 & 6 \\
\hline 7. & The level of inaccurate information effects the planning & 0.636364 & 7 \\
\hline 8. & Other government departments facilitate the PDMA during crises & 0.642424 & 8 \\
\hline 9. & Response to the disaster at time of crises & 0.606061 & 9 \\
\hline 10. & PDMA seek help from international organizations & 0.6 & 10 \\
\hline 11. & The response of PDMA in case of unexpected disaster & 0.593939 & 11 \\
\hline 12. & $\begin{array}{l}\text { Relation with metrological department for the forecasting of } \\
\text { disaster }\end{array}$ & 0.575758 & 12 \\
\hline 13. & $\begin{array}{l}\text { The level of crisis communication and cooperation of PDMA with } \\
\text { community facilities }\end{array}$ & 0.569697 & 13 \\
\hline 14. & Level of broadcasting of warning information to the public & 0.557576 & 14 \\
\hline 15. & $\begin{array}{l}\text { The management team provide a correct survey of the effected } \\
\text { people }\end{array}$ & 0.545455 & 15 \\
\hline 16. & $\begin{array}{l}\text { That risk awareness and education messages in your Country are } \\
\text { consistent with the "effective communication and education tools" }\end{array}$ & 0.539394 & 16 \\
\hline 17. & The response of people to the warning system & 0.533333 & 17 \\
\hline 18. & Rank the standard of readiness on part of resource organization & 0.533333 & 18 \\
\hline 19. & The level of public awareness program by PDMA & 0.527273 & 19 \\
\hline 20. & Logistics problem in a disaster for PDMA & 0.527273 & 20 \\
\hline 21. & The awareness of community to the warning system & 0.521212 & 21 \\
\hline 22. & Level of warning system in preventing the disasters & 0.515152 & 22 \\
\hline 23. & $\begin{array}{l}\text { Level of preparedness of local communities to mitigate natural } \\
\text { disasters in your country }\end{array}$ & 0.515152 & 23 \\
\hline 24. & Level of the training of PDMA officials regarding disasters. & 0.50303 & 24 \\
\hline 25. & $\begin{array}{l}\text { Level of understanding of the public of the risks of hazards in } \\
\text { your country }\end{array}$ & 0.442424 & 25 \\
\hline & \multicolumn{1}{|c|}{$\begin{array}{l} \\
\end{array}$} & \\
\hline
\end{tabular}

\section{The adequateness of media during disaster (RII 0.6909)}

The most significant factor according to RII and statistical means shows that the media has a role of vital importance during the natural calamities. Survey suggested that $30.3 \%, 33.3 \%$ and $18.2 \%$ people considered the role of media as medium, very high and high respectively (Table 1) with RII value equal to 0.6909 (Table 4). The role of media should be positive and must provide true and accurate information in the times of emergencies. The impact of negative media coverage creates more unstable behaviour among the society according to the survey, which must be avoided.

\section{Rescue, evacuation, shelter food should be provided by PDMA (RII 0.6667)}

According to PDMA and statistical means by the respondents this is one of the most significant factor and they agree with this that rescue, evacuation, shelter and food should be provided by PDMA during the disaster (RII 0.6667, $15.2 \%$ as very high). PDMA should check their 
warehouses for all relief commodities and should do proper planning according to the ADB criteria. Rescue operation, evacuation accompanied with provision of food and shelter must be provided by PDMA.

Table No. 4: Ranking Five Important Factors Affecting Disaster Response Criteria

\begin{tabular}{|l|l|c|c|}
\hline No & Important Factors Affecting Disaster Response Criteria & RII & Rank \\
\hline 1. & PDMA future disasters planning and awareness & 0.745455 & 1 \\
\hline 2. & The adequateness of media during disaster & 0.69090 & 2 \\
\hline 3. & $\begin{array}{l}\text { Rescue, evacuation, shelter food should be provided by PDMA } \\
\text { during crises }\end{array}$ & 0.666667 & 3 \\
\hline 4. & Level of volunteer's response during crises & 0.654545 & 4 \\
\hline 5. & Response of international organization during crises & 0.654545 & 5 \\
\hline
\end{tabular}

\section{Level of volunteer's response during crises (RII 0.6545)}

The fourth most important factor ranked by the respondents affecting the disaster criteria is volunteer's response. From the questionnaire study, it is seen that the highest ranked variable PDMA must ensure that response of volunteers should be improved before occurrence of any disaster as per respondents no one was satisfied to consider it as very high, $9.1 \%$ thought it as high, $39.4 \%$ as medium, $21.2 \%$ as low and $30.3 \%$ as very how (Table no. 1 ).

\section{Response of international organization during crises (RII 0.6545)}

The fifth most important ranked factor by the respondents according to RII is response of international organization during crises. From the questionnaire study, it is seen that the response is significantly low. PDMA must ensure that the response of international organization should be strong and timely for the relief commodities. Only $12.1 \%$ considered it very high, $36.4 \%, 21.2 \%, 27.3 \%$ and $3.0 \%$ rated it as high medium, low and very low, respectively (Table no. 1 ).

Table No. 5: Ranking Five Least Important Factors Affecting Disaster Response Criteria

\begin{tabular}{|l|l|c|c|}
\hline No & $\begin{array}{l}\text { Five Least Important Factors Affecting Disaster Response } \\
\text { Criteria }\end{array}$ & RII & Rank \\
\hline 1. & The awareness of community to the warning system & 0.521212 & 1 \\
\hline 2. & Level of warning system in preventing the disasters & 0.515152 & 2 \\
\hline 3. & $\begin{array}{l}\text { Level of preparedness of local communities to mitigate natural } \\
\text { disasters in your country }\end{array}$ & 0.515152 & 3 \\
\hline 4. & Level of the training of PDMA officials regarding disasters. & 0.50303 & 4 \\
\hline 5. & $\begin{array}{l}\text { Level of understanding of the public of the risks of hazards in } \\
\text { your country }\end{array}$ & 0.442424 & 5 \\
\hline
\end{tabular}

\section{Five least important Factors affecting Disaster, Response Criteria}

The survey picked up Q1, 2, 11, 15 and 12 as the least important factors affecting disaster response criteria in a descending order based on the survey response of $12.1 \%, 18.2 \%, 15.2$ $\%, 18.2 \%$ and $21.2 \%$ respectively categorized as very low (Table no. 1 ) and upon the values of RII provided in Table no. 3 and Table no. 5.

These questions deal with the awareness of community to the warning system (Q2), level of the warning system in preventing the disaster (Q1), level of preparedness of local communities to mitigate natural disasters in your country (Q11), level of training of PDMA officials 
regarding disasters (Q15) and level of understanding of the public of the risks of hazards in your country (Pakistan). Policy gaps in disaster management preparedness and response have been reported (Deen, 2010).

\section{CONCLUSIONS}

This study covered the fundamental concepts of disasters, disaster management, types of disasters, and damages of disasters in a brief historical and overall perspective with specific focus on Khyber Pakhtunkhwa, Pakistan. Pakistan has suffered from destructive natural disasters in the recent past, but we have failed to learn from it. Thus, this social ignorance and unawareness permeated the official handling of the disasters at the institutional level, and has slowed down the establishment of strong disaster-management strategies in PDMA.

In this research, disaster management has evaluated at a provincial level. It has been analyzed keeping in view the disaster response criteria given by ADB. The criteria provided by ADB are relatively mature and complex system in comparison to PDMA. Throughout the analyses, we examined the structural and organizational differences among the PDMA and disastermanagement criteria of ADB. PDMA yet has to reach to a level where it is seen as a successful and preserving organization that has the ability to deal with the disasters caused by nature and man-made agents.

\section{RECOMMENDATIONS}

Pakistan is a country which is prone to natural and man-made hazards. If measures are not taken to prepare ourselves as a society and as institution, the consequences of lack of preparedness can be multiplied.

1. An ICT based Early Warning System (EWS) is recommended, which can help community as well as disaster management authorities to prevent and minimizing losses against disaster.

2. Efforts to consolidate, unify and share data, methods and information management platforms should be strengthened for broadcasting and forecasting of any disaster.

3. The PDMA should use its available resources with maximum efficiency. Resource management should be done to create synergistic effects.

4. A community based disaster management (CBDM) program is recommended. CBDM promotes takes on board the local people, who can give affordable and incremental solutions. This will also encourage local community empowerment through involvement at ground levels. Early warning systems need to actively involve the communities at risk, facilitate public education and awareness of risks.

5. Governmental bodies and NGOs working on vulnerability assessments and risk reduction programs should engage in disaster risk assessment activities. They should keep close liaison with international organization.

6. PDMA should start public awareness and training programs for the community advancement and mitigation for different disasters for future planning. A flexible information system is required in order to centralize all hazard and risk-related information. Such a system must be capable of integrating, updated and new datasets.

7. To be fully effective, the survey and assessment needs to be carefully planned and organized beforehand. It usually calls for:

- Survey from the air.

- Survey by field teams.

- Accurate reporting from disaster management and other official authorities in or near the disaster area. 
8. While disaster management in Pakistan has its focus on rescue and relief, initiatives should be taken beforehand. It should include different local and international disaster mitigation and management training. During disaster holding the pressure and its impact on department is very high. Stress Management Training should also be provided to avoid panic in response situations.

9. During our discussions we observed lack of institutional willingness to initiate awareness campaigns. PDMA should improve correspondence with media persons and with local commodities and with government departments for initiation of awareness programs.

\section{References}

Carter, W. N. (2008). Disaster Management: A Disaster Manager's Handbook. Asian Development Bank, Metro Manila, Philippines.

Climate Change (2014). Intergovernmental Panel on Climate Change 2014. Impacts, Adaptation and Vulnerability: Regional Aspects. Cambridge University Press.

Coppola, D., \& Coppola, D. (2007). Introduction to International Disaster Management (2 ${ }^{\text {nd }}$ Ed.). ButterworthHeinemann.

David, K., Schrag, D., Dadi, Z., Ye, Q., \& Ghosh, A. (2017). Global climate, a risk assessment. Retrieved from: http://www.csap.cam.ac.uk/media/uploads/files/1/climate-change--a-risk-assessment-v9-spreads.pdf.

Deen, S. (2010). Pakistan 2010 floods: policy gaps in disaster preparedness and response. International Journal of Disaster Risk Reduction, 30(12), 341-349.

Human Rights Commission of Pakistan (2014). State of Human Rights. Retrieved from: https://www.scribd.com/document/291027079/HRCP-Annual-Report-2014-English-pdf.

Khan, N. (2016). Department of Defence and Strategic Studies Retrieved from: http://www.academia.edu/20439252/Seminar_paper.

Kreft, S., Eckstein, D., \& Melchior, I. (2017). Global climate risk assessment, who suffered the most from extreme weather events 1996-2015. Global Climate Risk Index. 1-32. Retrieved from:

https://germanwatch.org/de/download/16411.pdf.

Marrone, S., Nardone, R., Tedesco, A., D'Amore, P., Vittorini, V., Setola. R., De-Cillis, F., \& Mazzocca, N. (2013). Vulnerability modelling and analysis for critical infrastructure protection applications. International Journal of Critical Infrastructure Protection, 6(3), 217-227.

Mata-Lima, H., Alvino-Borba, A., Pinheiro, A., Mata-Lima, A., \& Almeida, J. A. (2013). Impacts of natural disasters on environmental and socio-economic systems: what makes the difference? Retrieved from:

http://www.scielo.br/scielo.php?pid=S1414-753X2013000300004\&script=sci_arttext\&tlng=en.

Mayhorn, C. B., \& McLaughlin, A. C. (2014). Warning the world of extreme events: a global perspective on risk communication for natural and technological disaster. Safety Science, 61, 43-50.

Munang, R., Thiaw, I., Alverson, K., Liu J., \& Han, Z. (2013). The role of ecosystem services in climate change adaptation and disaster risk reduction. Current Opinion in Environmental Sustainability, 5(1), 47-52.

Mustafa, D., \& Wrathall, D. (2011). Indus Basin Floods of 2010. Souring of a Faustian Bargain? Water Alternatives, 4(1), 72-85. Retrieved from: http://www.water-alternatives.org/index.php/volume4/v4issue1/127-a4-1-5/file.

Sayed, S. A., \& Gonzalez, A. P. (2014). Flood disaster profile of Pakistan: a review. Science Journal of Public Health, 2(3), 144-149.

UNDP Pakistan. (2017). One UN Disaster Risk Management Joint Programme (UNDP), Pakistan Disaster Reporting Handbook. Retrieved from: http://www.ndma.gov.pk/Documents/DRM_Plan/falak/Disaster\%20Reporting.pdf.

Wisner, B., Balaikie, P., Cannon, T., \& Davis, I. (2003). At Risk: Natural Hazards, People's Vulnerability and Disasters ( $2^{\text {nd }} E d$.). Rutledge. 